\title{
Miningo
}

\section{Rare earth elements in the international economic scenario}

http://dx.doi.org/10.1590/0370-44672014670162

\section{Carlos Enrique Arroyo Ortiz \\ Engenheiro de Minas, Doutor, \\ Departamento de Engenharia de Minas, \\ DEMIN- UFMG \\ carroyo@demin.ufmg.br}

\section{Elias Marques Viana Júnior}

Economista, Msc. Programa

de Pós-Graduação em Engenharia Mineral,

Escola de Minas, UFOP

elhias@yahoo.com.br

\section{As terras-raras no cenário econômico mineral}

\begin{abstract}
This article will focus on some relevant aspects of rare earths within the context of the mineral economy. It starts with a conceptual presentation of rare earths addressing both governmental actions, and the private sector. Then, briefly describes their chemical characteristics and their main applications. Finally, more emphasis will be given about some economic aspects: the supply chain structure, the mineral reserves, the production profile, the demand, supply and price analyses, both in the international and Brazilian contexts, and the exports and imports, highlighting China's participation in the rare earth market and concluding with the existence of a Chinese monopoly in the production of this product.
\end{abstract}

keywords: Rares Earths, Mineral Economics, China, Monopoly.

Resumo

O presente artigo versará sobre alguns aspectos pertinentes às terras-raras dentro do contexto da economia mineral. Iniciará por uma apresentação conceitual das terras-raras abordando ações, tanto governamentais, quanto do setor privado. Em seguida, descreverá, brevemente, suas características quimicas e suas principais aplicações. Por fim, será explanado, com mais ênfase, alguns aspectos econômicos: a estruturação da cadeia produtiva, as reservas minerais, o perfil da produção, análise de demanda e oferta e os preços, tanto no contexto internacional, quanto no brasileiro, assim como as exportações e as importações. O artigo destaca a participação da China no mercado de terras-raras abordando, ainda, a existência de monopólio chinês na produção desse minério.

Palavras-chave: terras-raras, economia mineral, China, monopólio.

\section{Introduction}

Although they do not have the same emphasis as other more well-known mineral commodities, such as iron, nickel and others, the rare earth elements have earned broad attention in the fields of mining activities related to research, exploration, production, and commercialization, as well as the application of these metallic elements. They have important repercussions for specific economic sectors of industry and commerce.

Foreseen for the next few years is a substantial growth in the use of rare earth elements, especially neodymium, samarium, mainly lanthanum, cerium and yttrium, for high-tech applications, including the manufacture of super magnets in the electronics sector and in the development of new materials and superconductors. In Brazil, the Governintention to enlarge investments in $\mathrm{R} \& \mathrm{D}$ and once more integrate a booming world market.

On the public sector side, the Ministry of Mines and Energy (MME) stated that rare earths should be considered as strategic assets, calling them "minerals with a future" in the National Mining Plan. The Ministry of Science, ment and companies have signaled the
Technology and Innovation (MCTI) also announced investments of $\mathrm{R} \$ 11$ million in research and development in the sector until 2016 (Sturari 2012).

The private sector follows in the same direction. In recent years, the number of requisitions presented to DNPM to prospect for rare earth mineral reserves has increased. In 2009, there were only 28 requests; in 2010, this number grew to 53 , peaking at 92 in 2011 and 200 in 2012. Some companies, like CBMM, have already begun to explore these elements on a trial basis. This company, the country's largest producer of niobium, extracts rare 
earth concentrates from its main mining tailings since last year, and, until 2014, expects to separate the elements and offer them in the market (Moutinho, 2013).

This article discusses a concep-

\section{Theoretical basis}

The rare earths are not naturally found as simple elements, they are normally associated with other minerals like phosphate and gold. The rare earth elements or rare earth metals, which are designated this way not because they are not abundant, but because that was the generic name of the oxides of most metallic elements of difficult separation, forming a set of 17 chemical elements.

\section{Metodology}

According to Gil (1999), the research can be classified as bibliographic and documentary, because it analyzes and documents an extensive bibliography, taking necessary care to validate the new proposals and suggestions brought by

\section{Production chain}

The rare earth elements undergo a complicated production chain until

products with market application are reached, as shown in Figure 1:

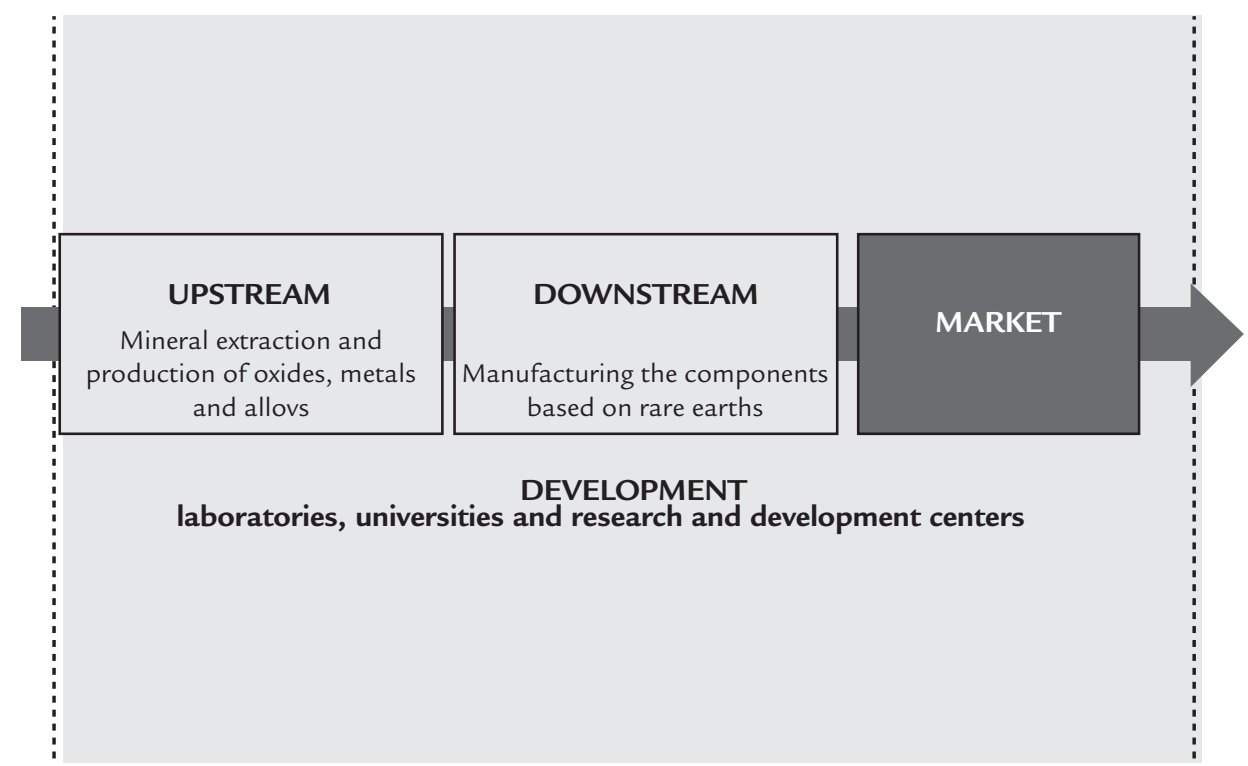

\section{Production Stages - Upstream}

Once found, the rare earth elements need to be extracted and separated generating oxides, metals and alloys that are used by industry. The first step consists in mining the ore, namely, mineral extraction and concentration of rare earth elements; depending on the characteristic of the mineral, the con- tual base for understanding what are effectively the rare earths and their main applications. Also approached is the international situation and the Brazilian landscape in the face of the multiple vari-
This includes the scandium (chemical symbol Sc), yttrium (Y) and the 15 elements of the Lanthanide series [from lanthanum (La) to lutetium (Lu)]. Cerium $(\mathrm{Ce})$ is the most abundant of the RE elements and the $25^{\text {th }}$ most abundant element in the Earth's crust. By its isotopic instability, promethium $(\mathrm{Pm})$ is the rarest of the rare earth elements (Rocio, 2012).

different styles of literature.

Our work used data from reserves, values of export and import, prices and others that reveal the economic structure of rare earth oxides. The main objective is to present an economic evaluation at both The second step is the extraction of the oxides, which deals in rare earth element separation and production of rare earth oxides; in this process, solvents are used in the separation.

The third step is the electrolysis process, whereby rare earth oxides take ables that involve the issue of rare earths. Economic aspects will also compose this work addressing issues related to production, trade, prices and the production chain of rare earths.

The most common applications of RE are as follows: permanent magnets, electrical and electronic circuits, exhaust gas catalysts, laser equipment, mobile phones, dyes in glasses and ceramics, high-refraction lenses and metallic alloys. Although abundant, the RE element-bearing minerals are difficult to extract, which increases their cost of production.

national and international levels.

Thus, through the calculated participation of mining in the total income from this economic activity, the real impact of the participation of China in the global market for rare earth elements is assessed.

Figure 1

Rare Earths Production Chain.

Source: MBAC. (2013)

the form of metals.

The fourth step is the light alloy casting, i.e. casting of rare earth metals into light alloys.

The Upstream supply chain is concentrated in a few regions (Figure 2), due to availability of resources and knowledge (technology). 
Figure 2

Location of Production Centers.

Source: MBAC.

(2013)

China currently holds approximately $85 \%$ of the global production of rare earth oxides, but Japan is the main

\section{Production Stages - Downstream}

Rare earths oxides, metals and alloys are used in several applications,

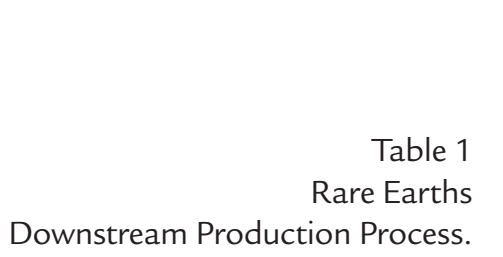

Source: MBAC. (2013)

\section{International economic conjuncture}

\section{Reserves}

The world is rich in rare earth metals, being very large the production potential of ores containing rare earth metals. Thus, great transformations can occur in the production profile. Even with the price increase in recent years, the world market is still very small compared to other markets, such as oil and iron ore. In
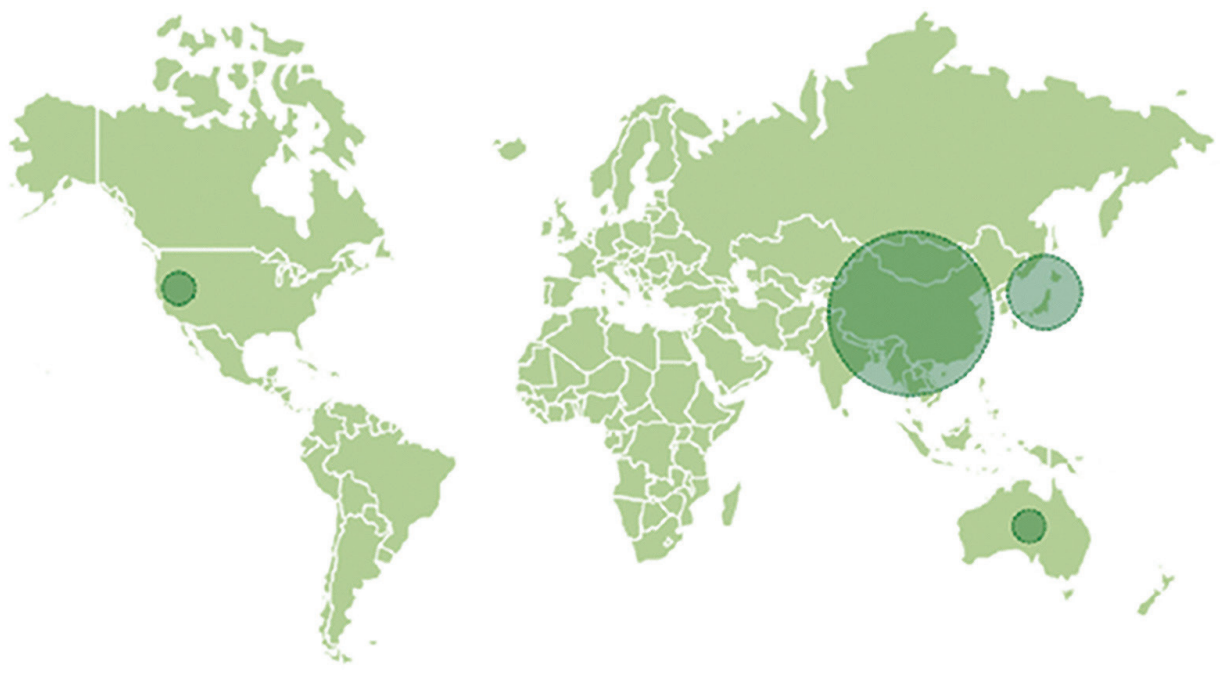

holder of the technology used in the transformation of rare earths. Both countries concentrate rare earth production, since

being especially important in the hightech industry. Based on the same steps the vast majority of companies that are located in China are Japanese, and 90\% of what Japan imports comes from China.

\begin{tabular}{c|c|c}
\multirow{2}{*}{ Extraction (oxides) } & $\mathrm{Ce}$ & Polishing powder \\
\cline { 2 - 3 } & $\mathrm{Eu}, \mathrm{Y}, \mathrm{Tb}$ & Phosphors \\
\cline { 2 - 3 } & $\mathrm{La}, \mathrm{Ce}$ & Alloy additives and catalysts \\
\hline Electrolysis (metals) & $\mathrm{Ce}, \mathrm{Pr}, \mathrm{Nd}$ & "Bonded" Magnets \\
\hline \multirow{2}{*}{ Light alloys casting } & $\mathrm{Pr}, \mathrm{Nd}, \mathrm{Sm}, \mathrm{Gd}, \mathrm{Dy}, \mathrm{Tb}$ & "Sintered” Magnets \\
\cline { 2 - 3 } & $\mathrm{La}, \mathrm{Ce}, \mathrm{Sm}$ & NiMH batteries
\end{tabular}

this way, the construction of an integrated production chain, which manages a large aggregation of value, is critical.

It is estimated that the total reserves of rare earth ores (measured and indicated) are up to 135.7 million tons. Of this total, China has more than $40 \%$, and the largest part lies in the deposit of Baiyun
Ebo (bastnaesita). Russia is singled out as the country that has the second largest reserve $(18 \%)$, composed mostly by loparite and apatite. Brazil has 16.17\% of world reserves, after which comes the United States, Australia, India, Malaysia and other countries. Figure 3 presents the reserves expressed in tons.

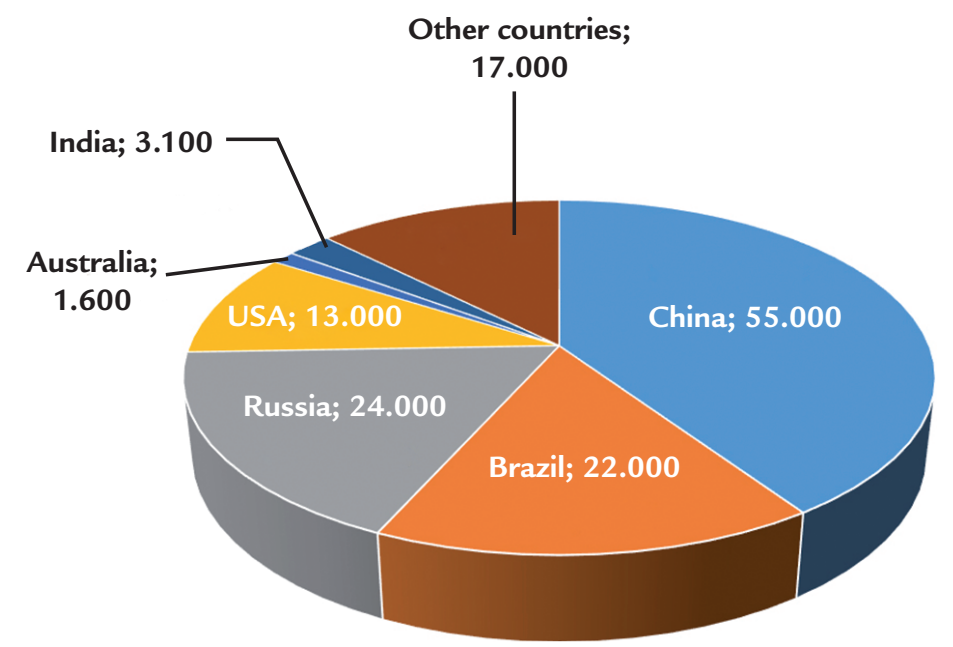




\section{Production}

China also continues in the lead of world production, with more than $87 \%$ of rare earth oxides produced in 2012 (95\% in 2011). China consumes more than $67 \%$ of world production, followed by Japan, the USA, and Germany. Although there is a lot of research on the subject, there are no efficient substitutes

\section{National conjuncture - ree in brazil}

Due to the recent appreciation of rare earth exploration, Brazil still has little tradition in this sector. However, as shown in previous sections, Brazil has considerable potential in the production of these elements, owning rare earth reserves that reach 120 million tons, which is 3 times more than the reserves measured in China (Sturari 2012).

In Brazil, Catalão I (GO) and Araxá (MG) mines have identified resources which outperform China's reserves. They are reserves containing rare earth, still with no economic extraction technology, but seeming to be quite feasible, considering the current prices of rare earths and the high levels of minerals.

The most expressive rare earth for the various uses of REE.

The main extraction plants of rare earths from China are located in Baotou. In that region alone, about 10 processing plants produce 200 different species of rare earth products. Baotou is placed second in production capacity in the world. The largest rare earth

mineral reserves of Brazil are located in the municipalities of Presidente Figueiredo (AM) and Catalão (GO). The estimated reserves are of 30 thousand tons of monazite, containing $7.56 \%$ content of rare earth oxides. Currently, the most promising ore is the one from Córrego do Garimpo, located in Catalão (GO), and its mining rights belong to Vale Fertilizantes S.A. (Humphreys, 2011).

According to a report by DNPM (2013), in the end of 2012, new minable reserves were approved in 2 areas of Araxá, with 14.20 and $7.73 \mathrm{Mt}$ of rare earth oxides contained, being the grades $3.02 \%$ and $2.35 \%$, respectively; and 1 area in Itapirapuã Paulista, with 97.96 thousand tons of rare earth oxides contained, and $4.89 \%$ grade. The con- production plant is located at Molycorp, Mountain Pass (USA). Rhône Poulenc, a pioneer in the extraction of rare earths, has two plants, La Rochelle (France), currently closed, and Freeport (USA) which produces oxides of rare earths with up to $99.999 \%$ purity (LoureiroLapido, 2013)

taining of this report elevates Brazil in the rank as the second largest holder of REE reserves in the world, shortly after China. Companies that hold these assets are: CBMM (14 Mt of minable reserves), CODEMIG (8 Mt of minable reserves) and Vale Fertilizantes S.A. Other reserves belong to Mineração Terras Raras (6 Mt of measured reserves, with $0.5 \%$ grade of rare earth oxides, totaling 30 Kt contained in the revaluation process); Indústrias Nucleares do Brazil - INB (609 thousand tons of minable reserves, with $0.103 \%$ grade of monazite with $422 \mathrm{t}$ contained), and VALE S.A. (17.2 thousand tons of rare earth in measured and indicated reserves, containing 57\% of monazite, which is equivalent to 9.7 thousand tons).

\section{Prices}

REE are negotiated in the private market. The prices are published periodically on sites like mineralprices.com and metal-pages.com. The elements are sold at levels of $99 \%$, in the form of

oxides or in alloys containing varied grade levels. For this reason, prices may vary depending on the quality and the quantity required in the applications.

Table 2 shows the evolution of

\begin{tabular}{c|c|c|c|c|c|c|c|c|c}
$\begin{array}{c}\text { Average Price } \\
\text { (US\$/t.) }\end{array}$ & 2003 & 2004 & 2005 & 2006 & 2007 & 2008 & 2009 & 2010 & 2011 \\
\hline $\begin{array}{c}\text { Monazite } \\
\text { Concentrate }\end{array}$ & 730 & 590 & 730 & 540 & 870 & 870 & 870 & 870 & 2.700 \\
\hline $\begin{array}{c}\text { Bastnaesite } \\
\text { Concentrate }\end{array}$ & 4.080 & 4.080 & 4.080 & 5.510 & 6.610 & 8.820 & 5.730 & 6.870 & $\mathrm{Nd}$ \\
\hline Mischmetal & 5.500 & 4.080 & 6.000 & 5.500 & 7.500 & 8.500 & 8.500 & 50.000 & 48.500
\end{tabular}

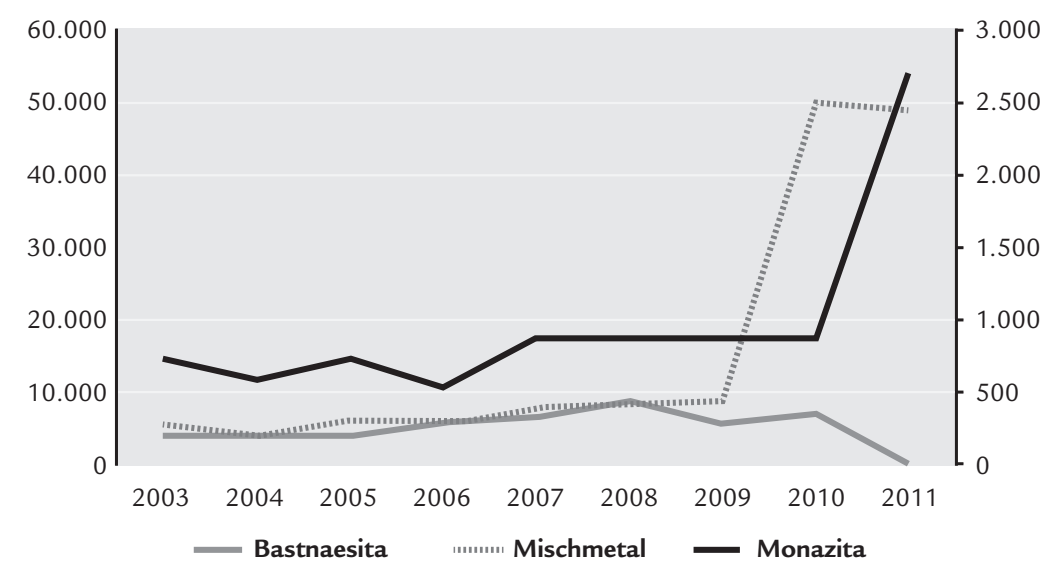

prices for some rare earth oxides, with minimum purity equal to $99 \%$, from the year 2003 until 2011. Figure 4, shows, graphically, the dynamics of the data of Table 2 .

Table 2

Average price of rare

earths in Brazil (2003-2011)

Source: DNPM (2013)

Figure 4

Rare earths price

evolution in Brazil (2003-2011)

Source: DNPM (2013) 
Looking at the chart above, it is seen that the prices of rare earths were stable from 2007 to 2009; however, due to the current supply crisis, the price of most REE has been rising continuously since the end of year 2009 .

In 2011, prices of 17 elements that form the rare earths used for the production of many modern products - magnets, fiber optics, cell phones, electric cars, high performance batteries, and wind power generators - reached a peak that scared most of the dependent companies of these inputs.

The price charged by some elements

\section{Demand}

The demand for REE has been increasing in recent years, both as compounds, such as metals, individually, and alloys. Even though there are rare earth mineral reserves in Brazil, as mentioned before, the country still does not have a demand that justifies the large-scale mining of REE.

It is likely that in the next ten years, there will be a substantial increase in consumption of REE in Brazil as a result of increasing hydrocarbon refining capacity,

\section{International trade}

Traditionally the USA and Japan are the biggest importers of rare earths. Germany, France, China and Brazil also have relative prominence in this trade. REE international trade, in 2010, by 10 major importing countries of this ore, reached the amount of approximately 70 thousand tons. Japan, the largest importer, participated with $25.71 \%$ of the total, representing approximately 18 thousand tons.

Although there are 10 countries with significant participation in rare earths imports, only 3 concentrate $60.71 \%$ of the total imported, namely: Japan, USA $(23.57 \%)$ and Germany (11.42\%).

Brazil participated with $2.07 \%$ of the total imported, representing 1,451 tons, including chemicals and manufac-

\section{Conclusions}

In the face of rapidly increasing technology advancement, it is possible to affirm that, over the coming decades; the REE will be in more demand and valued, providing the producing countries with a very important competitive advantage in the international market. came to be multiplied by 25 . This is due to China owning 90 percent of the global supply, and its forcing an increase in prices after export restrictions were imposed. The market imbalance was potentiated by consumption growth pulled by programs of innovations in consumer companies. Despite the price increase observed in recent years, there has been, at the end of 2011, an indentation in quotations of rare earths.

Summing the growth in demand and the restrictions of exports by China, it is expected to take some time for the global supply to meet the world demand.

the production of automobiles, engines and turbines production that require the use of permanent magnets and the possible production of high-definition screens for electronic gadgets.

The global demand of rare earth for 2010 was estimated at 134,000 tons/year for a worldwide production of 124,000 tons/year, being the largest consumer China, which is also by far the biggest producer, while Japan and many other countries in the West are totally

tured products. In 2011, Brazil imported chemicals and manufactured products with REE amounting to US\$53.64 million (FOB). These imports originated mainly from the following countries: for manufactured goods: China (74\%), Bulgaria (11\%), United States of America (9\%), Australia (2\%), and Belgium (2\%); and for chemical compounds, China (92\%), United States of America (3\%), France (3\%) and Spain (1\%). DNPM (2013).

With respect to exports in 2010 , the world trade turnover was approximately 80 thousand tons of rare earth compounds. In this respect, the domain is broadly Chinese, which in that year has exported approximately 40 thousand tons, i.e. $50 \%$ of exports. By comparison, the second country that most exported
Thus, prices should remain high in the short term. According to Humphreys (Humphreys, 2009), in the long term, with increased supply, prices tend to fall to the marginal cost of production.

It is also important to register that, generally, mineral extraction costs are increasing because of the low grades of ores and the increased costs of capital.

In China, production costs can increase due to environmental and social issues, in addition to the escalating costs of labor to be incorporated into the production and processing of rare earth metals.

dependent on imports and even recycling. (Seaman, 2010)

There were predictions that the demand would reach 180,000 tons/year in 2012 and 200,000 tons in 2014, and it was unlikely that the startup of new mines for production could balance the difference in the short term. As Chinese production must not exceed 160,000 tons, in the short term, it can be predicted that there will be an annual deficit of 40,000 tons/year in this scenario (Humphreys, 2011).

was Australia with approximately 11 thousand tons. The participation of Brazil among exporters is small, but it even so it sets up among the 10 leading countries. Its exports totaled only 527 tons in 2010.

In 2012, Brazil exported chemicals and manufactured products amounting to US\$ 1,996 million (FOB). The main country of destination of these exports of monazite was China $(100 \%)$. For the chemical compounds, the main country of destination was Spain (95\%), followed by the Dominican Republic (3\%), Argentina $(1 \%)$ and Chile (1\%).

For manufactured products, the main countries of destination were Angola (38\%), Canada (17\%), United States (16\%), United Kingdom (12\%) and Uruguay (4\%) (DNPM 2013).
This is the reason why China has been investing heavily in acquiring land and mineral reserves in other countries, particularly in Africa, but also in Brazil.

The data exposed also reveals that the global rare earth market follows a monopoly system headed by China, since
$90 \%$ of the production of oxides of low value and $99 \%$ of the oxides of high value are produced by this Asian country.

The Chinese monopoly on rare earth elements is concentrated in virtually all stages of the production chain, thus creating few opportunities for 
other countries. This results in uncertainties in the supply of products and great exposure to price surges, which consequently generates large profits for Chinese companies.

Another aspect that has been growing in recent years relates to the consumption of rare earth elements by China that in a few years will be responsible for half of the global demand, configuring itself as an oligopsony, since the other $50 \%$ of the demand belongs to only three countries.

This is fostering a growing search for new reserves of rare earths, as the market already knows of the economic advantages of the ore, and chases to break the Chinese monopoly.

Specifically in Brazil, this picture of economic concentration resulted in some proposals for development of a new mining regulatory framework.
Other countries also are seeking alternatives to break this domain through the integration of the production chain of rare earth within their own territories.

It is important to note that the success of these interventions relies on a strong investment in technical knowledge in the various phases of production, so that it is possible to build an highly technological industry with great benefits for the country.

\section{References}

STURARI, R. J. A. Terras-raras brasileiras: perspectivas de uma nova era. Disponível em <www.eme.eb.mil.br/ceeex/public/...NEP_CEEEx_Raul_Sturari_2012.pdf>. Acesso em: 10 jun. 2013

MOUTINHO, S. O novo ouro. Revista Ciência Hoje. Rio de Janeiro, Instituto Ciência Hoje, v. 52, n.1, 10, 2013.

ROCIO, M. A. R. Terras-raras: situação atual e perspectiva. BNDES Setorial, v 35, n.1, 2012

GIL, A. C. Técnicas de pesquisa em economia. (2ª Ed.) São Paulo, : Atlas,1999.

MBAC. Terras-raras: da mina ao mercado. Nov. 2013.

Departamento Nacional de Produção Mineral - DNPM. Terras-raras. Sumário Mineral. São Paulo, 2013.

LOUREIRO-LAPIDO, F. O Brasil e a reglobalização da indústria das terras raras. Rio de Janeiro: Cetem, 2013.

LOUREIRO, F. E. V. L. Terras-raras tipos de depósitos, recursos identificados e alvos prospectivos no Brasil. I Seminário Brasileiro de Terras-Raras, Rio de Janeiro, 2011.

ROSENTAL, S. Terras-raras. Dn: SEMINÁRIO BRASILEIRO DE TERRAS-RARAS, Rio de Janeiro, 2008.

HUMPHREYS, D. Unravelling the causes of the mineral price boom. Resources Policy, v. 34, 2009.

SEAMAN. Rare earth and clean energy: analysing China's upper hand, IFRI. 2010.

HUMPHRIES, M. rare earth elements: the global supply chain. Congressional Research Service, 2011.

Received: 27 August 2014 - Accepted: 25 September 2014. 